\title{
36-72 Aylık Çocukların Dil Gelişim Özelliklerinin Çeşitli Değişkenler Bakımından İncelenmesi
}

\author{
Derya Eryılmaz \\ Karabük Üniversitesi \\ Să̆llk Yüksekokulu \\ orcid.org/0000-0002-4089-8762 \\ Mehmet Geyik \\ Karabük Üniversitesi \\ Sağglk Yüksekokulu \\ orcid.org/0000-0002-9523-3856
}

\author{
Gizem Ulad1* \\ Karabük Üniversitesi \\ Sağllk Yüksekokulu \\ orcid.org/0000-0003-4023-5624 \\ Merve Öztürk \\ Karabük Üniversitesi \\ Sağllk Yüksekokulu \\ orcid.org/0000-0002-4033-8562
}

\section{Öz}

Bu araştırmanın temel amacı; 36-72 ay çocukların cinsiyet, yaşadıkları bölge, kardeş sayısı ve öğretmenin deneyim süresinin alıcı dil becerilerine etkisini Peabody Resim Kelime Testi aracılığıyla incelemektir. Araştırmanın katılımcıları; Elazı̆̆, Hatay, Kocaeli ve Konya illerindeki 36-72 ay normal gelişim gösteren 191(98 kı, 93 erkek) çocuktan oluşmuştur. Çocukların demografik bilgilerini belirlemek amactyla araştırmacı çocuğun cinsiyet, kardeş sayısı, annenin öğrenim durumu, babanın öğrenim durumu, sosyal durum, gelir düzeyi, okul öncesi eğitime devam etme durumu ve öğretmenin deneyim süresi soruların yöneltmiştir. Bu çalışmada, nicel araştırma türlerinden tarama modeli ve kesitsel yöntemden yararlanılmıştır. Araştırmada veriler SPSS programıyla analiz edilmiştir. Verilerin analizinde; Normallik Testi, t-Testi ve ANOVA kullanılmıştır. Peabody Resim Kelime Testi'nden aldıkları puanlar dikkate alındığında, 36-72 ay çocukların dil gelişimlerine, cinsiyet, yaşadıklar bölge, öğretmenin deneyim süresi faktörlerinin etkili olduğu $(p<0.05)$, kardeş sayısı faktörünün ise etkili olmadı̆̆g $(p>0.05)$ saptanmıştır.

Anahtar Kelimeler: Peabody Resim-Kelime Testi, Dil, Çocukta Dil Gelişimi, 36-72 Aylik Çocuklar

\section{Examination of Language Developmental Characteristics of 36-72 Month Children in Terms of Various Variables}

\section{Abstract}

The main aim of this reseach is to analyze the effect of children's gender, region of residence, number of siblings, and duration of the experience of the teacher on 36-72 month children's receptive language skills using Peabody Picture Vocabulary Test. The participants of the research consist of 191 children (98 female, 93 male) who show 36-72 month normal development in Elazlğ, Hatay, Kocaeli and Konya. In order to determine demographic information about children, questions reated to gender, the number of siblings, mother's educational background, father's educational level, social status, income level, pre-school education, the duration of the experience of the teacher were asked. In this study, survey method and cross-sectional method were used. Data were analyzed with SPSS program. In the analysis of data; Normality Test, t-Test and 
ANOVA were used. Considering the scores obtained from the Peabody Picture Vocabulary Test, the language development of 36-72 months children were affected by gender, region of residence, duration of experience of teacher $(p<0.05)$, however the number of siblings has no effect in their language development ( $p>0.05)$.

Keywords: Peabody Picture Vocabulary Test, Language, Language Development of Child, 36-72 Month Children

\section{Giriş}

36-72 ay gelişim dönemindeki çocuğun merak duyguları, öğrenme algıları, zıt kavramları kullanma, keşfetme ve soru sorma becerileri; uzun cümleler, benzerlikler ve farklılıklar, sebep-sonuç, zaman, şart, yer ilişkileri kurmaları; cümle yapılarının yetişkinlerle benzerlik göstermeleri, isteklerini ayrıntılarıyla anlatmaları, sohbet etmeleri, başkalarının kelimelerini taklit etmeleri, sorulan sorulara kendi çabaları ile cevap vermeye çalışmaları dil gelişim özelliklerindendir (Karakaya, 2007).

Dil gelişimini açıklayan birçok kuram vardır. Bunlar; davranışçı, biyolojik, bilişsel öğrenme, sosyal öğrenme ve sosyal etkileşim kuramlarıdır. Davranışçı kuram, dil kazanımında bebeklerin konuşulanları taklit etmesi ve erişkinlerin ödüllendirmelerle bebeğin çıkardığı sesleri pekiştirerek desteklemeleri ve çevrenin etkisiyle de geliştirilmesi üzerinde durur. Kurama göre, çocuk yaşamına dil tankı boş olarak başlar, çevresinden sağlanan deneyimler ile bu tankı zamanla doldurarak dil edinimi gerçekleşir (Topbaş, 2015). Biyolojik kuramın temeli ise çocukların dil kurallarını uygulamak için doğuştan getirdikleri kapasiteleri olduğuna ve kendi kendilerine dili edindiklerine dayanır (Baykoç Dönmez, 1986). Bilişsel öğrenme kuramı, dil gelişiminin, bilişsel gelişime paralel olduğunu, dilin diş dünyaya ilişkin bilişsel izlenimler yoluyla geliştiğini ve bu nedenle bilişsel gelişimin bir sonucu olduğunu savunur (Deniz, 2015). Sosyal öğrenme kuramı kişinin dil edinimini; doğduğu süreçten beri etrafındakileri taklit ederek, model alarak, çevresini izleyerek; pekiştirici ve düzeltici geri bildirimler vermesi ile gerçekleştiğini savunur. Çocuğun dil çevresinin rolü, gelişimi boyunca artarak devam eder. Sosyal etkileşim kuramcılarına göre biyolojik, davranışsal, bilişsel ve sosyal gibi birçok faktörün gelişim sürecini etkilediğini, birbirlerini etkileyerek geliştiğini ve karşılıklı birbirlerine dayanarak var olduklarını savunurlar (Deniz, 2015; Temel, Bekir, Yazıc1, 2014).

Dil gelişimi geçmişten günümüze deneysel ve kuramsal açıdan ilgi çekmiş ve çeşitli çalışmalara konu olmuştur. Günümüzde halen dil gelişimi üzerine çalışmalar sürmektedir. Dil bilimciler dil gelişimini incelerken genetik mi, çevre mi yoksa biliş mi etkili sorusu üzerinde durmuşlardır (Topbaş, 2015). Bazı noktalarda görüş ayrılı̆̆ına giderken bazı noktalarda ise ortak bir paydada buluşmuşlardır. Her bir kuramın dil gelişimine katkısı vardır. Bu yüzdendir ki her bir kuram ayrı ayrı düşünülemez, hepsine ihtiyacımız olmasıyla beraber bir bütün olduğunu görmekteyiz (Topbaş, 2015).

Dil gelişimini etkileyen birçok etmen vardır. Bunlar zeka, cinsiyet, beyin, sosyal çevre ve aile, sosyo-ekonomik etmenler, ailenin eğitim durumu, iki dillilik, oyun ve sağlık durumudur. Dil gelişimi zekâ ve zihin gelişimi ile doğru orantılıdır. Çünkü algı, 
bellek, imgelem ve uslamlama gibi zihin becerileri geliştiği kadar dil gelişimi gerçekleşmektedir. Somut algılardan soyut kavramlara yükselmek ve bu kavramları birbirleriyle ilişki içinde kullanmak, duygu ve düşünceleri ifade etmek zekâ yardımıyla olmaktadır. Bu sebeple zekânın geliştiği yıllar dilin de geliştiği yıllardır (Binbaşoğlu, 1990). Cinsiyet faktörü açısından bakıldığında, kız çocukları sözel uyaranlara, erkek çocukları ise görsel uyaranlara daha fazla tepki vermektedirler. Bunun etkisiyle erken dönemlerde, kız çocukları her koşulda, erkek çocuklardan daha çok sözcük sayısına sahip olmaktadırlar (Temel, Bekir, Yazıc1, 2014). Beyin gelişimi dil edinimi sürecinde önemli bir yapıtaşıdır. Çünkü beynin temel işlevlerinden biri de dildir. Bireyin doğuştan getirdiği bilişsel dil bilgisinin işlenebilmesi için diğer destekleyici beyin yapılarının da tamamlanması gerekmektedir (Bekir, Temel, Yazıcı, 2014).

Bebekler konuşmayı, genellikle kendi aile bireylerinin çevrelediği sosyal ortam içinde günlük dil alışverişleriyle öğrenmektedir. Bebeğin ailesi ve çevresi tarafından kullanılan kelimelerin çokluğu bebeklerin daha fazla öğrenmelerine olanak sağlamaktadır. Bebekler, bakıcıları tarafından ne kadar çok sözel uyaran alırsa, genellikle daha geniş bir kelime haznesine sahip olurlar. Çocuğa sunulan sözel uyaranların zenginliği dil gelişimine olumlu yönde etkilediği bilinmektedir (Bayhan, Artan, 2005). Dil gelişiminde ki en önemli etken ailedir. Çocukların dil gelişimleri ailelerin sosyoekonomik düzeylerine göre farklılık göstermektedir. Alt sosyoekonomik ailelerin çocukları sağlık, motivasyon (isteklendirme), zekâ ve dil gelişimleri açısından olumsuz etkilenmektedirler. Yüksek sosyoekonomik düzeydeki ailelerin çocuklarının ise kelime hazinesi, soru sayısı, cümle uzunluğu bakımından daha üstün oldukları bilinmektedir. Bu fark kısmen, yüksek zekâ düzeyinin göstergesi olduğu söylenebilse de, eşit zekâ seviyesindeki çocuklarda bile, yüksek sosyoekonomik ailelerden gelen çocuklar daha elverişli ortamlarda yetişmektedirler. Anne babasıyla birlikte zaman geçiren çocuklar daha düzgün konuşmaktadırlar. Ailelerin eğitim seviyeleri ve sosyoekonomik durumları arttıkça aileler konuşmaya daha çok önem verdiklerinden çocuklarına daha iyi model oluşturmakta, çocukların çabuk ve düzgün konuşmalarına önem vermektedirler (Yavuzer, 1993). İki ayrı dilin konuşulduğu ortamda büyüyen ya da farklı iki dili edinmek durumunda kalan çocuklar, başlangıçta tek dil öğrenen çocuklara göre daha yavaş bir gelişim göstermektedirler. Küçük çocuklar dilin ses ve duyuş özelliklerine karşın daha açık algılama potansiyellerine ve daha keskin kulağa sahip olduklarından ikinci bir dili öğrenmede yetişkinlerden daha üstün oldukları ileri sürülmektedir (Heuchert, 1989; Türker, 2000; Şimşek-Bekir, 2004; Bekir, Temel, Yazıcı, 2014).Çocuk oyun ortamında ses bilimi, söz dizim ve anlambilim kurallarını keşfetme imkânı bulur. Oyun oynarken farklı kişilerle çeşitli duygu, ton ve ritimde konuşurlar. $\mathrm{Bu}$ onların kendilerini kontrol etme ve öz düzenleme becerileri açısından farkındalıklarının geliştiğinin bir göstergesidir(Aksoy, 2014).Sağlık, dil gelişimini etkileyen en önemli faktörlerden biridir. Çocuğun hem psikolojik, hem de fizyolojik yönden sağlıklı olması, gelişmesini ve olgunlaşmasını sağlamaktadır. Çocuğun sağlık durumunun iyi olmasıyla beraber çocuk daha enerjik ve neşeli olacaktır. Buna bağlı olarak babıldama, gı̆̆ıldama, mırıldanma gibi aktivitelere daha çok yönelmektedirler. Bu aktiviteler çocuğun dil edinim sürecini hızlandırmaktadır (Aydın, 1997). 
İnsanı diğer varlıklardan ayıran ve onlardan üstün kılan en önemli niteliği, dilidir. Dilin insana özgü ve en etkin iletişim aracı olarak kabul edilmesi, birçok araştırmacının ve düşünürlerin ilgi odağı olmuştur (Ünalan, 2012). Kültürel kimliğin kazanılması, kültürel mirasın aktarılması, sosyal iletişimin sağlanması, eğitimin sürdürülmesi, psikolojik davranışların ifade edilmesi ve evrensel bilgi aktarımları gibi birçok alanda fonksiyonel rolleri yüklenen dil, bilimin gelişmesiyle sosyal bilimlerdeki araştırmacıların ilgi odağı olup, araştırmalarda da özel bir konu alanı olarak bir bilim dalı haline gelmiştir.

\subsection{Araştırmanın Amacı}

$\mathrm{Bu}$ araştırmanın temel amacı, 36-72 ay çocukların alıcı dil becerilerini cinsiyet, yaşadıkları bölge, kardeş sayısı ve öğretmenin deneyim süresinin etkisi var mıdır sorularına yanıt aranmıştır:

- Çocukların dil gelişim puanları cinsiyete manidar düzeyde farklılık göstermekte midir?

- Çocukların dil gelişim puanları çocuğun yaşadığı bölgeye manidar düzeyde farklilik göstermekte midir?

- Çocukların dil gelişim puanları kardeş sayısına göre manidar düzeyde farklılık göstermekte midir?

- Çocukların dil gelişim puanları öğretmenin deneyim süresine göre manidar düzeyde farklılık göstermekte midir?

\section{Yöntem}

\subsection{Araştırma Modeli}

Nicel araştırma deseninde tasarlanan bu çalışmada, nicel araştırma türlerinden tarama modeli ve kesitsel yöntemden yararlanılmıştır. Nicel araştırma, en genel anlamda verilerin sayılar biçiminde olduğu görgül araştırmalardır. Bir teoriyi test etmek üzere, sayısal ölçümler ve istatistikî teknikler kullanılarak analiz edebilecek bir problem durumunu araştırmayı ifade etmektedir (Kıncal, 2015). Tarama modeli bir araştırma evreninin eğilim, tutum ya da görüşlerini bu evrendeki bir örneklemle çalışarak nicel ya da sayısal olarak tanımlamaya imkân sağlar. Bu araştırmalar, örneklemden evrene genelleme yapmak amacıyla, veri toplamada yapılandırılmış mülakatları ve anketleri kullanan kesitsel ve boylamsal çalışmaları içerir (Creswell, 2013). Kesitsel yöntem, bir olgunun ya da örneklemin belli bir zamandaki durumunu tespit etmeyi amaçlayan araştırma türüdür. Kesitsel yöntem, yaşın artması ile oluşan değişimleri betimlemeye yardım eden gelişimsel çalışmalarda çok sıklıkla kullanılan bir yöntemdir. Özellikle, bebeklik ve çocukluktan itibaren gelişimsel süreçlerin değişimini incelemede kullanılmaktadır. Kesitsel yöntem; farklı yaşlardan bireylerin belirli davranışlarının aynı zaman içerisinde ölçülerek veya gözlemlenerek karşılaştırılmasını gerektiren yöntemdir. Araştırmacı, ilgilendiği yaşlardan her birini yansıtan birey gruplarını belirler. Bu yaş gruplarından aynı zamanda veriler toplar ve bu yaş gruplarının verilerini karşılaştırır (Tanrı̈ğen, 2011). 


\subsection{Evren ve Örneklem}

Araştırmanın evrenini, 2016-2017 yıllarında, Elazı̆̆, Hatay, Kocaeli ve Konya illerinde, Diyanet İşleri Başkanlığı'na bağlı Kur'an kursuna ve T.C. Aile ve Sosyal Politikalar Bakanlığı'na bağlı kreşlere giden ve bu kurumlara gitmeyen 32-76 aylık çocuklar oluşturmaktadır. Araştırmanın örneklemini, Elazı ̆ ilinden 22'si kız 21'i erkek, Hatay ilinden 26'sı k1z 24'ü erkek, Kocaeli ilinden 25'i k1z 25'i erkek, Konya İlinden 25'i kız 23'ü erkek olmak üzere toplam 191 çocuk oluşturmaktadır.

Tablo 1. 36-72 Ay Çocukların Dil Gelişiminin Yaşa, Bölgelere ve Cinsiyete Göre Dağılımı

\begin{tabular}{|c|c|c|c|c|}
\hline & & $\mathbf{N}$ & $\%$ & Toplam \\
\hline \multirow{3}{*}{ Yaş } & $36-48$ ay & 45 & 23,5 & \multirow{3}{*}{191} \\
\hline & 49-60 ay & 63 & 32,9 & \\
\hline & 61-72 ay & 83 & 43,4 & \\
\hline \multirow{4}{*}{ Bölge } & Elazığ & 43 & 22,5 & \multirow{4}{*}{191} \\
\hline & Hatay & 50 & 26,1 & \\
\hline & Kocaeli & 50 & 26,1 & \\
\hline & Konya & 48 & 25,1 & \\
\hline \multirow{2}{*}{ Cinsiyet } & Kiz & 98 & 51,3 & \multirow{2}{*}{191} \\
\hline & Erkek & 93 & 48,6 & \\
\hline
\end{tabular}

\subsection{Veri Toplama Arac1}

$\mathrm{Bu}$ araştırmada gerekli verileri toplamak amacıyla Peabody Resim-Kelime Testi kullanılmıştır.

Peabody Resim-Kelime Testi: A.B.D'de Lloyd Dunn tarafından hazırlanıp geliştirilmiştir. Test, özellikle kelime bilgisinin gelişimini ve dil gelişim düzeyini saptamaktadır. Testin standardizasyonu 4200 kişilik bir grupta yapılmıştır. Test iki kısımdan oluşmaktadır. İlk kısımda çocuğa ve ailesine ait bir bilgi formu doldurulur. $\mathrm{Bu}$ bilgi formunda çocuğun cinsiyeti, kaç kardeş olduğu, okul öncesine gidip gitmediği, öğretmenin deneyim süresi, anne ve babanın eğitim düzeyi, gelir düzeyi ile ilgili bilgileri içerir. İkinci kısımda alıcı dil düzeyini belirleyen test maddeleri bulunur.

Testin türü performans testidir. Bireysel ve 2-12, 2,5 17,5 yaş çocuklarına uygulanır. Testin uygulama süresince zaman sinırlaması yoktur, ancak ortalama 10-15 dakikada yanitlanabilir. Test üzerinde 4'er resim bulunan 100 karttan meydana gelir. Testin güvenirliliği 0,71 ile 0,81 arasında değişmektedir. Testin tekrarı güvenirliği ise 0,52 ve 0,90 arasında bulunmuştur. Testin ölçüt bağımlı geçerliği; Stanford Binet Zekâ testi ile 82 ile 86; Weshler çocuklar için zekâ ölçeği ile 41 ile 74 bulunmuştur. Kaynaklarda Türkiye'de yapılan uygulamalara ait geçerlik ve güvenirlik bilgilerine rastlanmamıştır. Testin puanlaması, her doğru yanıt için 1 puandır. Puanların toplamı testin hem puanını oluşturur (Akt. Kurnaz, 2006).

\section{Bulgular}

$\mathrm{Bu}$ bölümde, araştırma sorularına ilişkin verilerin çözümlenmesinden elde edilen bulgular sırasıyla verilmiştir. 


\subsection{Birinci Araştırma Sorusuna İlişkin Bulgular ve Yorum}

"Çocukların dil gelişim puanları, cinsiyete göre manidar düzeyde farklılık göstermekte midir?" araştırma sorusuna yanıt aramak amacıyla elde edilen verilerin normallik testi sonuçları ve bağımsız örneklemler için t-Testi ile çözümlenerek elde edilen bulgular Tablo 2 ve Tablo 3 'te verilmiştir.

Tablo 2. Çocukların Cinsiyetlerine Göre Peabody Resim Kelime Testi Puanlarının Normallik Testi Sonuçları

\begin{tabular}{lccccc}
\hline Cinsiyet & Ortalama & Kişi Sayısı & $\begin{array}{c}\text { Standart } \\
\text { Sapma }\end{array}$ & Basıklık & Çarpıklık \\
\hline Erkek & 68,441 & 93 & 7,9543 &,- 182 &, 041 \\
Kız & 65,388 & 98 & 9,2253 &,- 526 &,- 189 \\
\hline Toplam & 66,874 & 191 & 8,7422 &,- 262 &,- 172 \\
\hline
\end{tabular}

Tablo 2 incelendiğinde, puan ortalamaları ile erkek ve kız çocuklarının cinsiyetleri arasında normal bir dağılım görülmektedir. Testten alınan puanlara bakıldı̆̆ında erkek çocukların puanlarının ortalamalarının, kız çocuklarının puan ortalamalarından yüksek olduğu sonucuna ulaşılmıştır.

Tablo 3. Kız ve Erkek Çocukların Peabody Resim Kelime Testinden Aldıkları Puanların t-Testi Sonuçları

\begin{tabular}{lcccccc}
\hline \multicolumn{1}{c}{ Cinsiyet } & N & $\overline{\boldsymbol{X}}$ & $\mathbf{S}$ & sd & $\mathbf{t}$ & $\mathbf{P}$ \\
\hline K1z & 98 & 65,388 & 9,2253 & \multirow{2}{*}{189} & $-2,444$ & \multirow{2}{*}{015} \\
Erkek & 93 & 68,441 & 7,9543 & & & \\
\hline
\end{tabular}

Kız ve erkek çocuklarının puan ortalamaları arasında manidar düzeyde bir fark göstermektedir $(\mathrm{p}<.05)$. t-Testi sonuçlarına göre erkek çocukları $(\bar{X}=68,441) \quad \mathrm{k}$ ız öğrencilerden $(\bar{X}=65,388)$ daha yüksek puan almıştır. Bu bulgu dil gelişimi ile cinsiyet arasında anlamlı bir ilişkinin olduğu şeklinde de yorumlanabilir.

\section{2. İkinci Araştırma Sorusuna İlişkin Bulgular ve Yorum}

“Çocukların dil gelişim puanları, yaşadıkları bölgeye göre manidar düzeyde farklılık göstermekte midir?" araştırma sorusuna yanıt aramak amacıyla elde edilen verilerin normallik testi sonuçları ve bağımsız örneklemler için tek yönlü ANOVA ile çözümlenerek elde edilen bulgular Tablo 4 ve Tablo 5 'te verilmiştir.

Tablo 4. Çocukların Yaşadıkları Bölgeye Göre Dil Gelişim Puanlarının Normallik Testi Sonuçları

\begin{tabular}{lccccc}
\hline Şehir & Ortalama & Kişi Sayısı & SS & Basıklık & Çarpıklık \\
\hline Elazı̆̆ & 67,744 & 43 & 10,0002 &, 261 &,- 851 \\
Hatay & 62,420 & 50 & 5,8067 &,- 424 &,- 422 \\
Kocaeli & 71,500 & 50 & 7,7440 &,- 203 &,- 241 \\
Konya & 65,917 & 48 & 8,7418 &,- 630 &, 059 \\
\hline Toplam & 66,874 & 191 & 8,7422 &,- 262 &,- 172 \\
\hline
\end{tabular}

Tablo 4 incelendiğinde, puan ortalamaları ile bölgeler arasında normal bir dağılım görülmektedir. Testten alınan puanlara göre en yüksek ortalama Kocaeli 
Bölgesinde iken en düşük ortalamanın da Hatay Bölgesinde olduğu sonucuna ulaşılmıştır. Elazı̆̆ ve Konya bölgeleri ise Kocaeli ve Hatay Bölgeleri arasında bulunmaktadir.

Tablo 5. Yaşadıkları Bölgeye Göre Çocukların Peabody Dil Gelişim Testinden Aldıkları Puanların ANOVA Sonuçları

\begin{tabular}{lccccc}
\hline $\begin{array}{l}\text { Varyansın } \\
\text { Kaynağı }\end{array}$ & $\begin{array}{c}\text { Kareler } \\
\text { Toplamı }\end{array}$ & sd & $\begin{array}{c}\text { Kareler } \\
\text { Ortalaması }\end{array}$ & F & p \\
\hline Gruplar arası & 2138,452 & 3 & 712,817 & 10,765 & \multirow{2}{*}{000} \\
Gruplar içi & 12382,533 & 187 & 66,217 & & \\
\hline Toplam & 14520,984 & 190 & & & \\
\hline
\end{tabular}

Analiz sonuçları Tablo 5'te, çocukların puan ortalamaları ile bölgeler arasında anlamlı bir farklılık olduğunu göstermektedir, $F(3,187)=10,765, p<.05$. Başka bir deyişle, çocukların dil gelişimleri, yaşadıkları bölgeye bağlı olarak anlamlı bir şekilde değişmektedir. Farklar normallik testi sonuçlarına göre, Kocaeli bölgesinde $(\bar{X}=71,500)$ çocukların dil gelişim puanları, Hatay bölgesinden $(\bar{X}=62,420)$, Konya bölgesinden $(\bar{X}=65,917)$ ve Elazı̆̆ bölgesinden $(\bar{X}=67,744)$ daha yüksek olduğu belirlenmiştir.

\section{3. Üçüncü Araştırma Sorusuna İlişkin Bulgular ve Yorum}

"Çocukların dil gelişim puanları, kardeş sayılarına göre manidar düzeyde farklılık göstermekte midir?" araştırma sorusuna yanıt aramak amacıyla elde edilen verilerin normallik testi sonuçları ve bağımsız örneklemler için tek yönlü ANOVA ile çözümlenerek elde edilen bulgular Tablo 6 ve Tablo 7'de verilmiştir.

Tablo 6. Çocukların Kardeş Sayılarına Göre Dil Gelişim Puanlarının Normallik Testi Sonuçları

\begin{tabular}{lccccc}
\hline Kardeş sayısı & \multicolumn{7}{c}{ Ortalama } & Kişi Sayısı Standart Sapma & Basıklık & Çarpıklık \\
\hline 1 & 65,929 & 56 & 10,1388 &,- 616 &,- 165 \\
2 & 68,265 & 83 & 8,3346 &,- 344 &,- 074 \\
3 & 65,673 & 52 & 7,5218 &, 107 &,- 311 \\
\hline Toplam & 66,874 & 191 & 8,7422 &,- 262 &,- 172 \\
\hline
\end{tabular}

Tablo 6 incelendiğinde, çocukların puan ortalamaları ile kardeş sayıları arasında normal bir dağılım görülmektedir. Testten alınan puanlara bakıldığında iki kardeş olan çocukların diğerlerine göre ortalamalarının daha yüksek olduğu sonucuna ulaşılmıştır.

Tablo 7. Kardeş Sayılarına Göre Çocukların Peabody Dil Gelişim Testinden Aldıkları Puanlara Göre ANOVA Sonuçları

\begin{tabular}{lccccc}
\hline Varyansın kaynağı & Kareler toplamı & sd & Kareler ortalaması & F & p \\
\hline Gruplar arası & 285,659 & 2 & 142,830 & & \\
Gruplar içi & 14235,325 & 188 & 75,720 & 1,886 &, 154 \\
\hline Toplam & 14520,984 & 190 & & & \\
\hline
\end{tabular}


Çocukların puan ortalamaları ile kardeş sayıları arasındaki fark, anlamlı bulunmamıştır, $\mathrm{F}(2,188)=1,886, \mathrm{p}>.05$. Sonuçlara göre, tek $(\bar{X}=65,929)$ olan çocukların, iki kardeş $(\bar{X}=68,265)$ olan çocukların ve üç kardeş $(\bar{X}=65,673)$ olan çocukların dil gelişimleri arasında kardeş sayısının etkili olduğu görülmemiştir.

\subsection{Dördüncü Araştırma Sorusuna İlişkin Bulgular Ve Yorum}

"Çocukların dil gelişim puanları, öğretmenin deneyim süresine göre manidar düzeyde farklılık göstermekte midir?" araştırma sorusuna yanıt aramak amacıyla elde edilen verilerin normallik testi sonuçları ve bağımsız örneklemler için tek yönlü ANOVA ile çözümlenerek elde edilen bulgular Tablo 8 ve Tablo 9'da verilmiştir.

Tablo 8. Öğretmenin Deneyim Süresine Göre Dil Gelişim Puanlarının Normallik Testi Sonuçları

\begin{tabular}{lrrccc}
\hline Deneyim süresi & Ortalama & \multicolumn{2}{c}{ Kişi Sayısı Standart Sapma } & Basıklık & Çarpıklık \\
\hline 0 & 66,500 & 42 & 8,2203 &,- 738 &,- 147 \\
1-3 yıl & 66,429 & 63 & 9,5861 &,- 048 &,- 289 \\
4-7 yıl & 61,563 & 32 & 6,5743 &,- 528 &, 094 \\
8 yıl ve daha fazla & 70,833 & 54 & 7,4549 &, 255 &,- 253 \\
\hline Toplam & 66,874 & 191 & 8,7422 &,- 262 &,- 172 \\
\hline
\end{tabular}

Tablo 8 incelendiğinde, çocukların puan ortalamaları ile öğretmenlerin deneyim süresi arasında normal bir dağılım görülmektedir. Testten alınan puanlara bakıldığında sekiz yıl ve daha fazla deneyimi olan öğretmenlerin, deneyim süresi daha az olan öğretmenlere göre ortalamalarının daha yüksek olduğu sonucuna ulaşılmıştır.

Tablo 9. Öğretmenin Deneyim Süresine Göre Çocukların Peabody Dil Gelişim Testinden Aldıkları Puanlara Göre ANOVA Sonuçları

\begin{tabular}{lccccc}
\hline Varyansın kaynağı & Kareler toplamı & sd & $\begin{array}{c}\text { Kareler } \\
\text { toplamı }\end{array}$ & F & p \\
\hline Gruplar arası & 1760,136 & 2 & 880,068 & \multirow{2}{*}{12,871} & \multirow{2}{*}{000} \\
Gruplar içi & 9982,804 & 146 & 68,375 & & \\
\hline Toplam & 11742,940 & 148 & & & \\
\hline
\end{tabular}

Tablo 9'da görüldüğü gibi çocukların puan ortalamaları ile öğretmenlerin deneyim süresi arasında anlamlı bir farklılık olduğu bulunmuştur, F $(2,146)=12,871$, $\mathrm{p}<.05$. Başka bir deyişle, çocukların dil gelişimleri, öğretmenin deneyim süresine bağlı olarak anlamlı bir şekilde değişmektedir. Farklar normallik testi sonuçlarına göre, sekiz yıl ve daha fazla $(\bar{X}=70,833)$ deneyimi olan öğretmenlerin çocukların dil gelişimleri üzerinde, dört ve yedi yıl $(\bar{X}=61,563)$ arasında deneyimi olan öğretmenden, bir ve üç y1l $(\bar{X}=66,429)$ arasında deneyimi olan öğretmenden ve deneyim süresi bilinmeyen $(\bar{X}=66,500)$ öğretmenden daha etkisi olduğu belirlenmiştir.

\section{Tartışma}

Çalışmadan elde edilen test sonuçları incelendiğinde, kız ve erkek çocuklarının Peabody Resim Kelime testlerinden aldıkları puan ortalamalarına bakıldığında, cinsiyet faktörünün dil düzeyleri arasında farklılığa neden olduğu sonucu ortaya 
çıkmıştır. Ancak bu başarı oranındaki farklar değerlendirmeye alınacak kadar önemli değildir. Erkek çocukların kız çocuklarına oranla daha yüksek puan alma sebebinin cinsiyete göre değil, ele alınan örnekleme dayalı veya yaşantılar ile ilgili bir farklılaşma olduğu sonucuna ulaşılabilir. Yapılan başka araştırmalarda dil gelişimini etkileyen etmenler incelendiğinde, cinsiyet ile dil gelişimi arasında önemli bir ilişkinin olmadığ 1 savunulmaktadır.

Öztürk (1995), okul öncesi eğitim kurumlarına giden ve gitmeyen 100 ilkokul birinci sınıf öğrencilerinin alıcı ve ifade edici dil düzeyleri karşılaştırılmıştır. Araştırmasında kız ve erkek çocukların alıcı dil düzeylerini karşılaştırmış ve anlamlı bir fark bulmamıştır. Temel (2000) yaptığı çalışmada, çocukların dil gelişimleri ile cinsiyet arasında anlamı bir ilişki olmadığı sonucunu bulmuştur. Erdoğan ve arkadaşlarının (2005) araştırmalarında, alt sosyoekonomik çevreden gelen çocukların cinsiyete göre dil gelişimi puanları arasındaki farkın istatistiksel olarak önemli olmadığ1 sonucunu bulmuşlardır. Araştırma sonucuna göre 36-72 ay çocuklarında dil gelişim düzeyini etkilemede cinsiyetin önemli bir faktör olmadığı söylenebilir.

Test sonuçları incelendiğinde, yaşadıkları bölge faktörünün dil düzeyleri arasında farklılığa neden olduğu sonucu ortaya çıkmıştır. Test sonuçlarına bakıldığında en yüksek ortalama Kocaeli iken Elazığ, Konya ve Hatay illeri bu sırayı izlemektedir. Test uygulanan bölgeler incelendiğinde Kocaeli ilindeki veriler kurumsal bir kolejde, Elazı̆̆ ilindeki veriler özel kreşlerde, Konya ilindeki veriler özel bir kreşte ve Kur'an kursunda, Hatay ilindeki veriler ise köy okullarından toplanmıştır.

Okul öncesi kurumundaki ortam, uyarıcı zenginliği açısından önemlidir. Kolejlerdeki uyaranların devlet okullarına göre daha iyi durumdadır. Koleje giden çocukların üst sosyoekonomik düzeyde olduğu, diğerlerinin sırasıyla daha alt düzeye sahip olduğu düşünülmektedir. Üst sosyoekonomik düzeydeki öğrencilerin dil gelişimi puanları, alt sosyoekonomik düzey ve orta sosyoekonomik düzeydeki öğrencilerin dil gelişimi puanlarından daha yüksek olduğu saptanmıştır. Ayrıca, çocuğun içinde bulunduğu sosyoekonomik düzey arttıkça dil gelişim puanlarında artış olduğu gözlenmiştir. Bu veriler eğitim eşitsizliğinin önemli bir göstergesidir. Çocukların dil gelişimi açısından gelişimsel bir geriliği olmamasına rağmen sosyoekonomik dezavantajları olmaları nedenleriyle puan farklılıkları olmuştur. Bu durum Türkiye'nin önemli bir sorunudur. Türkiye kolejlerdeki eğitim olanaklarını köy okullarına da sağlayabilirse dil gelişim puanları arasındaki fark azalabilir.

Ailenin ekonomik durumu faktörünün dil gelişimini etkilediği birçok araştırma sonucunda yer almıştır. Bu araştırmanın sonucunu destekleyen araştırmalar mevcuttur. Davaslıgil (1985), tarafından alt ve üst sosyoekonomik ve kültürel düzeyde bulunan ilkokul birinci sınıfa devam eden 100 öğrencinin dil gelişimine okulun etkisini incelemiştir. İki grup arasında sözcük bilgisi bakımından fark olduğu görülmüştür. Sosyoekonomik ve kültürel bakımdan düşük öğrencilerin tanıdıkları isimlendirme testinde, sosyoekonomik ve kültürel düzeyi yüksek öğrenciler kadar başarılı olmadıkları görülmüştür. Erkan(1990), araştırmasında, sosyoekonomik ve eğitim düzeyi düşük ailelerin 4-5 yaşlarındaki çocukları ile sosyoekonomik düzeyi yüksek 
olan ailelerin 4-5 yaşlarındaki çocukların kullandıkları dil yapısı yönünden incelenmiştir. Alt sosyoekonomik düzeyden gelen çocukların ev ortamlarının dil kazanımını engellediğini belirtmiştir. Temel (2000), 0-72 ay çocuklarının dil gelimi ile sosyoekonomik düzey ilişkini saptamak amacıyla yürüttüğü araştırmada, dil gelişimi ile sosyoekonomik düzey arasında önemli bir ilişki olduğunu ortaya koymuştur. Sonuç olarak ailelerin sosyoekonomik durumunun çocukların dil gelişim düzeylerinde önemli bir etken olduğu söylenebilir. Ailelerin ekonomik düzeyi yükseldikçe çocukların dil gelişim puanları yükselmektedir.

Test sonuçları incelendiğinde, kız ve erkek çocuklarının Peabody Resim Kelime testlerinden aldıkları puan ortalamalarına bakıldığında, kardeş sayısı faktörünün dil düzeyleri arasında anlamlı fark bulunmamıştır. Dil gelişimini etkileyen etmenlerden kardeş sayısı ile ilgili yapılan başka çalışmalar incelendiğinde benzer sonuçlara ulaşıldığı görülmüştür. Öztürk (1995), araştırmasında okul öncesi eğitim kurumlarına giden ve gitmeyen 100 ilkokul birinci sınıf öğrencilerinin alıcı ve ifade edici dil düzeylerini karşılaştırılmıştır. Kardeş sayısısın çocukların alıcı dil düzeyleri arasında anlamlı bir fark bulunmamıştır. Aydoğan ve Koçak (2003), anaokuluna giden çocuklar üzerinde yaptıkları çalışmalarında kardeş sayılarının dil gelişimi üzerinde etkili olmadığını saptamışlardır. Erdoğan ve arkadaşlarının (2005), yaptığı çalışmada alt sosyo ekonomik bölgeden gelen çocukların kardeş sayısına göre gruplar arası farkın önemli olmadığını saptamışlardır.

Aile içi nüfusun az olması durumunda anne babanın çocuklarına göstereceği ilgi ve zaman çok nüfuslu ailelere kıyasla daha fazla olmaktadır. Ancak burada önemli olan kardeş sayısından çok gösterilen ilginin ve harcanan zamanın niteliğidir. Bununla beraber çok nüfuslu ailelerde, çocukların ebeveynleri dışında iletişim ve etkileşim kurabileceği kişi sayısının daha fazla olması, dil gelişimini olumlu yönde etkileyebilmektedir. Ayrıca çocuklarda sözcük dağarcığı gelişimi aile ve yakın çevreyle ilgili olduğu kadar, çocuğun sahip olduğu kültürel olanaklarla ve zengin uyarıcı bir çevre ile de ilgilidir. Alt sosyoekonomik düzeyden gelen çocukların, dille ilgili deneyim geçireceği zengin uyarıcı bir çevrelerinin bulunmaması, ailede sözcük dağarcığının kısıtlı oluşu, dili kullanan iyi bir modelin olmayışı ve çocuklarla sözlü iletişimin yetersiz olması bu çocukların dil gelişiminde geride kalmalarına neden olmaktadır.

Öğretmenlerin deneyim sürelerine bakıldığında 8 yıl ve daha fazla deneyime sahip öğretmenlerin öğrencileri, deneyim süresi daha az öğretmenlerin öğrencilerine kıyasla testten aldıkları puan ortalamalarının daha yüksek olduğu görülmektedir. Bu durum gösteriyor ki deneyim süresi fazla olan öğretmenlerin uyguladığ yöntemlerin dil gelişimi üzerinde daha etkili olabileceğidir. Deneyimi olan öğretmenlerin materyal kullanım, çocukla iletişim, problem çözme ve sınıf yönetimi becerileri bakımından yeni başlayan veya deneyimi daha az olan öğretmenlere göre daha gelişmiş olabilir. Bu konuyla ilgili yeterince çalışmaya ulaşılmadığı için başka çalışmaların nasıl sonuçlandığı üzerine bir karşılaştırma yapılamamıştır. 


\section{Sonuç ve Öneriler}

Araştırmadan elde edilen sonuçlara göre 36-72 ay çocukların dil gelişimlerine, Peabody Resim Kelime Testinden aldıkları puanlarda cinsiyet, yaşadıkları bölge, öğretmenin deneyim süresi faktörlerinin etkili olduğu $(p<0.05)$, kardeş sayısı faktörünün ise etkili olmadığ 1 ( $p>0.05)$ saptanmıştır. Ancak erkek çocukların kız çocuklarına oranla daha yüksek puan alma sebebinin cinsiyete göre değil, ele alınan örnekleme dayalı veya yaşantılar ile ilgili bir farklılaşma olabileceği, dil gelişim düzeyini etkilemede cinsiyetin önemli bir faktör olmadığı sonucuna ulaşılmıştır. Yaşadıkları bölgede üst sosyoekonomik düzeydeki çocukların dil gelişim puanları, alt sosyoekonomik ve orta sosyoekonomik düzeydeki çocukların dil gelişim puanlarından daha yüksek olması, ailelerin ekonomik düzeyinin, çocukların dil gelişimlerinde etken olduğu görülmüştür. Öğretmenin deneyim süresine bakıldığında ise, deneyim süresi fazla olan öğretmenlerin uyguladığı yöntemlerin dil gelişimi üzerinde daha etkili gözlemlenmiştir. Son olarak kardeş sayısı faktörü, çocukların dil gelişimi üzerinde doğrudan etkili olmayıp anne-baba, yakın çevre ve zengin uyarıcı ile farklılaşabileceği sonucuna ulaşılmıştır. Araştırmadan elde edilen sonuçlar doğrultusunda aşağıdaki genel öneriler geliştirilebilir:

- Dil edinimi ve gelişimi çok küçük yaşlarda başlaması, dil gelişimine okul öncesi döneminden önce de önem verilmesini önemli kılmaktadır. Bu yüzden evde ebeveynler okulda ise eğitimciler gereken özeni göstermelidirler.

- Çevre koşulları dil gelişimini olumlu veya olumsuz etkileyebilmektedir. Yetersiz çevre koşullarında yetişen çocuklar hem sözcük dağarcığ1 hem de genel olarak dil becerileri açısından kendilerinden daha iyi sosyoekonomik düzeydeki yaşıtlarından geridedir. Sosyoekonomik düzeyi düşük çocukların dil gelişimi çevreden yeterince sağlanamiyorsa, okul öncesi dönemden başlayarak dili zenginleştirici programlar hazırlanabilir. Böylece bu çocukların dil gelişimleri arasındaki farklar azaltılabilir.

- Birey dili kullanırken anlayabilme ve kullanabilme yeteneğine sahip olursa yaşam boyu başarılı olmaktadır. Bu da dilin zengin sözcük dağarcığı, hatasız bir telaffuz ve anadilinin kurallarına uygun olacak biçimde kullanma ile mümkündür. Okulöncesi öğretmenleri ve ebeveynler bu konuda bilgilendirilebilir. Verilen bu eğitimin sonucu çocukların dil gelişim düzeylerinin etkisini belirlemeye yönelik araştırmalar planlanabilir.

- Çocuklar doğdukları andan itibaren iletişim içindedirler. Çocukların bezlerini değiştirme, banyo yaptırma, yemek yedirme, oyun oynama vs. sırasında konuşmak çocuğun günlük dil becerilerini kazanmalarına yardımcı olabilir. Eğer çocuğun kardeşleri varsa iletişimleri desteklenerek model oluşturulabilir.

- Öğretmenlere, yıpranma payı ve tecrübeleri göz önüne alınarak dil gelişimi hakkında bilgilendirici seminerler düzenlenebilir.

- Dil gelişimi ile diğer gelişim alanları arasındaki ilişkileri inceleyen araştırmalar yapılabilir. 
- Alt sosyokültürel çevrede yaşayan ailelerin dil gelişimi konusunda Milli Eğitim Bakanlığı, Üniversiteler, Belediyeler, Sağlık Bakanlığı ve TRT bilgilenmeleri için programlar hazırlayabilir.

- $\mathrm{Bu}$ araştırmanın sonuçları dikkate alınarak bundan sonra yapılacak araştırmalara 1şık tutması için geliştirilen öneriler ise,

- Bu araştırmada örneklemi 36-72 ay grubu çocuklar oluşturmuştur. Çalışmada cinsiyet, kardeş sayısı, yaşadıkları bölge ve öğretmenin deneyim süresi faktörleri üzerinde durulmuştur. Bundan sonra yapılacak çalışmada okul öncesine devam eden veya etmeyen, alt-üst sosyoekonomik ailelerden gelen çocukların dil gelişimleri incelenebilir ya da çalışmaya farklı şehirler eklenerek o bölgeye ait dil özellikleri de çalışılabilir.

- Bu çalışmada 36-72 ay grubu çocukların alıcı dil becerileri üzerinde çalışılmıştır. Bundan sonraki çalışmalarda 36-72 ay çocukların ifade edici dil becerileri çalışılabilir.

\section{Kaynakça}

Aksoy, A. B. (2014). Her yönüyle okul öncesi eğitim ve okul öncesi eğitimde oyun (Birinci baskı). Ankara: Hedef CS Basın Yayın.

Arslan, E. (2015). Erken çocukluk döneminde gelişim (Birinci baskı). Ankara: Eğiten Kitap Yayınevi.

Aydın, F. Ö. (1997). Başbakanlık sosyal hizmetler çocuk esirgeme kurumunda bulunan 5-6 yaş grubu çocuklara uygulanan dil eğitim programının dil gelişimine etkisi. (Yayımlanmamış Yüksek Lisans Tezi). Gazi Üniversitesi, Sosyal Bilimler Enstitüsü.

Aydoğan, Y. ve Koçak, N (2003). Okul öncesi çocukların dil gelişimlerine etki eden faktörlerin incelenmesi, Milli Ĕğitim Dergisi, 159, 76-81.

Bayhan, P. ve Artan İ. (2005). Çocuk gelişimi ve eğitimi. İstanbul: Morpa Kültür Yayınları. Baykoç-Dönmez, N. ve Meziyet, A. (1992). 12-30 aylık Türk çocuklarında dilin kazanılması, Gazi Üniversitesi Ĕ̆itim Fakültesi Dergisi, 8(3), 115-161.

Berk, L. E. (2013). Çocuk gelişimi (Ed: Bekir, O. Çev: Dönmez, A.). Ankara: İmge Kitabevi.

Creswell, J. (2013). Araştırma deseni (Ed: Demir, S., B.). Ankara: Eğiten Kitap Yayınevi.

Cüceloğlu, D. (1999). İnsan ve davranışı. İstanbul: Remzi Kitapevi.

Davaslıgil, Ümit. (1985). Farklı sosyoekonomik ve kültürel çevreden gelen birinci sınıf çocuklarının dil gelişimde okulun etkisi. İstanbul: Eebiyat Fakültesi Basımevi.

Deniz, E. (2015). Eğitim psikolojisi (Yedinci baskı). Ankara: Maya Yayın Dağıtım Eğitim Danışmanlık.

Deniz, E. (2010). Erken çocukluk döneminde gelişim (İkinci baskı). Ankara: Maya Yayın Dağıtım Eğitim Danışmanlık.

Diken, İ.H. (2014). Erken çocukluk eğitimi (İkinci baskı). Ankara: Pegem Akademi Yayınevi. Erdoğan, S. Bekir, H, Ş., Aras, S, E. (2005) Alt sosyoekonomik bölgelerde ana sınıfına devam eden 5-6 yaş grubundaki çocukların dil gelişim düzeylerine bazı faktörlerin etkisinin incelenmesi, Çukurova Üniversitesi, Sosyal Bilimler Enstitüsü Dergisi, 14(1), 231-246. 
Erkan, P. (1990). Sosyo-ekonomik ve eğitim düzeyleri farklı olan ailelerin 48-60 aylar arasındaki çocuklarının dil yapılarının incelenmesi. (Yayımlanmamış Bilim Uzmanlığı Tezi). Hacettepe Üniversitesi. Ankara.

Karacan, E. (2000). Çocuklarda dil gelişimi etkileyen faktörler. Sürekli Tıp Eğitim Dergisi. 7, 254258.

Karakaya, Ş. (2007). Dil gelişimi ve dil politikası. Ankara: Akçağ Yayınevi.

Kıncal, R. (2015). Bilimsel araştırma yöntemleri (Beşinci baskı). Ankara: Nobel Akademik Yayıncilik.

Kol, S. (2011). Erken çocuklukta bilişsel gelişim ve dil gelişimi, Sakarya Üniversitesi Eğitim Fakültesi Dergisi, 21, 1-21.

Kurnaz, F., B. (2006). Peabody resim kelime testinin madde yanlılı̆̆ı açısından incelenmesi, Hacettepe Üniversitesi, Sosyal Bilimler Enstitüsü

Martinet A. (1998). İşlevsel genel dilbilim. İstanbul: Multilingual Yayınevi.

MEB. (2013), Çocuk gelişimi ve eğitimi dil gelişim modülü. Ankara: MEGEP.

Öztürk, H. (1995). Okul öncesi eğitim kurumlarına giden ve gitmeyen ilkokul birinci sınıf öğrencilerinin alıcı ve ifade edici dil düzeyleri. (Yayınlanmamış Yüksek Lisans Tezi). Gazi Üniversitesi, Sosyal Bilimler Enstitüsü, Ankara.

Piaget. (2007). Çocukta dil ve düşünme (Ed: Günaydın Y. T. Çev: Siyavuşgil, S. E.). Ankara: Palme Yayınları.

Tanrı̈ğen, A. (2011). Bilimsel araştırma yöntemleri. Ankara: Anı Yayıncılık.

TDK. (2011), Türkçe sözlük. Ankara: Türk Dil Kurumu Yayınları

Temel, F.(2000). Erken çocukluk döneminde dil gelişimi: sosyoekonomik düzey ve cinsiyet ilişkisi, Gazi Üniversitesi Ĕ̆itim Fakültesi Dergisi, 20(2), 39-53.

Temel, F., Bekir, H. ve Yazıcı, Z. (2014). Erken çocuklukta dil edinimi. Ankara: Vize Basın Yayın.

Topbaş, S., S. (2015). Dil ve kavram gelişimi (Altıncı baskı). Ankara: Kök Yayınevi.

Tural, A. (1979). Dil gelişimi ve eğitimi el kitabı. Ankara: Hacettepe Yayınları.

Ünalan Ş. (2012). Dil ve kültür (Beşinci baskı). Ankara: Eskiyeni Yayınları.

Vardar B. (1999). Yirminci yüzyıl dilbilimi. İstanbul: Multilingual Yayınevi.

Vygotsky. (1998). Düşünce ve dil (İkinci baskı). Ankara: Toplumsal Dönüşüm Yayınları.

Yavuzer, H. (1993). Çocuk psikolojisi. İstanbul: Remzi Kitapevi.

Yazıcı, Z. (2015). Erken çocukluk döneminde gelişim. Ankara: Eğiten Kitap Yayınevi.

Yeşilyaprak, Binnur. (2017). Eğitim psikolojisi (18. baskı). Ankara: Pegem Akademi Yayınevi. 